\title{
POLECENIE PANOWANIA NAD STWORZENIEM (RDZ 1,26-28) W EKOLOGICZNEJ HERMENEUTYCE BIBLII
}

Fragment Rdz 1,26-28 znany jest przede wszystkim jako opowiadanie o stworzeniu człowieka na obraz Boży (Imago Dei). ${ }^{1}$ Zawiera on jednak także boski nakaz, by ludzie rozmnażali się oraz czynili sobie ziemię poddaną. Ze względu na terytorialne rozpowszechnienie chrześcijaństwa, passus ten odegrał istotną rolę w kształtowaniu kultury niemal na całym świecie. Polecenie Boga skierowane do pierwszych ludzi i jego interpretacja w teologii legły u podstaw oskarżeń światopoglądu judeochrześcijańskiego o spowodowanie lub poważne przyczynie się do kryzysu ekologicznego. Do tego boskiego polecenia odwołują się zarówno przeciwnicy, jak i zwolennicy działań na rzecz ochrony środowiska naturalnego. Stanowisko teologów i biblistów również nie jest w dyskusji ekologicznej jednogłośne. Podczas gdy jedni traktują słowa z Księgi Rodzaju jako nakaz odpowiedzialnej troski o stworzenie, rozumianej jako gospodarowanie (stewardship), inni widzą w tych samych słowach udzielenie człowiekowi mandatu do dowolnej eksploatacji zasobów naturalnych. Ta kluczowa kwestia została zauważona także przez papieża Franciszka, który w encyklice Laudato $S i$ ' postulował konieczność odczytywania tekstów biblijnych we „właściwej hermeneutyce”, bez sprecyzowania jednak, na czym

Artykuł prezentuje wyniki studiów przeprowadzonych w ramach projektu badawczego: „Ekologiczna hermeneutyka Biblii: cele, założenia, rezultaty, zastosowania”, realizowanego na Uniwersytecie Kardynała Stefana Wyszyńskiego w Warszawie. Projekt został sfinansowany ze środków Narodowego Centrum Nauki przyznanych na podstawie decyzji numer DEC-2013/09/N/HS1/03628. 
ona polega. ${ }^{2}$ Tym bardziej stosowne wydaje się zatem przeprowadzenie pogłębionej refleksji naukowej nad rozumieniem polecenia przekazanego w Rdz 1,26-28 i jego oddziaływaniem na sposób myślenia i działania odbiorców biblijnego przekazu.

W artykule zostanie zarysowany rozwój ekologicznej hermeneutyki Biblii stanowiącej pewne novum w badaniach biblijnych. Zostaną też przedstawione zagadnienia tekstualne związane $\mathrm{z}$ analizowanym fragmentem oraz omówione ujęcia i odczytywanie $\mathrm{Rdz}$ 1,26-28 w głównych nurtach ekologicznej hermeneutyki Biblii: apologetycznym, radykalnym i neoortodoksyjnym.

\section{Rozwój ekologicznej hermeneutyki Biblii}

Ruch ekologiczny, rozumiany jako ochrona środowiska naturalnego przed degradacją i nadmierną eksploatacją ze strony ludzi, rozwinął się na fali ruchów kontestacyjnych cechujących przełom lat sześćdziesiątych i siedemdziesiątych XX w. Jednocześnie zaczęły się podnosić krytyczne głosy pod adresem światopoglądu chrześcijańskiego opartego na Biblii, wskazujące na jego odpowiedzialność za kryzys środowiskowy. Do pierwszych oskarżycieli należał Lynn T. White Jr., którego teza stała się trwałym punktem odniesienia do dyskusji na temat odpowiedzialności Biblii i chrześcijaństwa za kryzys ekologiczny. ${ }^{3}$ Jego zdaniem światopogląd chrześcijański, szczególnie zaś przekonanie o uczynieniu człowieka na obraz Boży oraz udzielonym mu nakazie panowania nad światem, odpowiada za rozpowszechnienie na świecie dualizmu między człowiekiem a przyrodą. Istotę problemu stanowić miał zatem fragment Rdz 1,26-28, zwłaszcza zaś słowa z Rdz 1,28: ,... abyście zaludnili ziemię i uczynili

2 Por. Fra n c i s z e k, Encyklika Laudato Si', nr 67; tłum. pol.: http://w2.vatican. $\mathrm{va} /$ content/dam/francesco/pdf/encyclicals/documents/papa-francesco_20150524 enciclica-laudato-si_pl.pdf(dostęp: 24 V 2015).

3 Por. L.T. W h i t e Jr., The Historical Roots of Our Ecologic Crisis, Science 155/1967, s. 1203-1207. 
ją sobie poddaną; abyście panowali" (cyt. za Biblią Tysiąclecia). Podobnego zdania byli Carl Amery, ${ }^{4}$ Jürgen Moltmann ${ }^{5}$ i wielu innych. ${ }^{6}$

Wobec oskarżeń wysuwanych pod adresem Biblii konieczne stało się przeprowadzenie analizy tego zagadnienia przez teologów i biblistów. Problematyka związana z ekologią w Biblii była podejmowana w ciągu ostatnich dziesięcioleci wielokrotnie i na różne sposoby. ${ }^{7}$ Norbert Lohfink już 1977 r. postulował konieczność podjęcia pogłębionej refleksji nad właściwą interpretacją fragmentu Rdz 1,26-28. ${ }^{8}$ Badacze próbowali wykazać, że Biblia nie przekazuje tak negatywnego stosunku człowieka do natury, jak stwierdził to Lynn T. White Jr. ${ }^{9}$ Niestety, w tej dyskusji dość długo niezauważony pozostawał fakt, że środowisko naturalne było dewastowane nie tylko przez chrześcijan, lecz również przez wyznawców innych religii, więc remedium na kryzys ekologiczny nie może być ubóstwienie natury. ${ }^{10}$

$\mathrm{Z}$ biegiem czasu rozwinęło się kontekstualne podejście interpretacyjne, znane pod nazwą ,hermeneutyka ekologiczna” (ecological hermeneutics), „hermeneutyka ekosprawiedliwości” (ecojustice hermeneutics), „hermeneutyka środowiskowa” (environmental hermeneutics), "lektura ekologiczna” (ecological reading), względ-

4 Zob. C. A m e r y, Das Ende der Vorsehung. Die gnadenlosen Folgen des Christentums, Reinbeck 1972.

5 Por. J. M o $1 \mathrm{t}$ m a n n, God in Creation: An Ecological Doctrine of Creation, London 1985.

6 Stanowiska L.T. White’a Jr., jego zwolenników oraz przeciwników zostały szczegółowo omówione w: R.F. S a d o w s k i, Filozoficzny spór o rolę chrześcijaństwa w kwestii ekologicznej, Warszawa 2015.

7 Podstawowa literatura związana z tematyką ekologiczną w Biblii zob.

T. Tw a r d z iło w s k i, Ekologiczna hermeneutyka Biblii, Warszawa 2015, s. 19-21.

8 Por. N. L o h f i n k, Unsere großen Wörter. Das Alte Testament zu Themen dieser Jahre, Freiburg 1977, s. 156-171.

9 Szczegółowe omówienie tego zagadnienia zob. T. Tw a r d z i ł o w s k i, Ekologiczna hermeneutyka Biblii, s. 37-41.

10 Por. P. D e Plu n kett, Ekologia - stereotypy i rzeczywistość. Od Biblii do naszych czasów, Poznań 2008, s. 17-21.

11 Definicja hermeneutyki środowiskowej (environmental hermeneutics) jest znacznie szersza i dotyczy hermeneutycznej refleksji nad interpretacją wszelkiego 
nie „krytyka ekologiczna” (ecological criticism). ${ }^{12}$ Termin ,hermeneutyka" należy tu rozumieć jako określenie podejścia interpretacyjnego, choć doprecyzowanie definicji tego kluczowego pojęcia nastręcza trudności także prekursorom hermeneutyki ekologicznej. ${ }^{13}$

W ramach ekologicznej hermeneutyki Biblii skrystalizowały się trzy główne nurty: apologetyczny, radykalny i neoortodoksyjny. Należy w tym miejscu wspomnieć także o niemającym charakteru refleksji naukowej nurcie antyekologicznym, którego zwolennicy postulują nieograniczoną eksploatację zasobów naturalnych jako uprawnioną przez tekst biblijny i chcianą przez Boga. Ten ostatni przypadek w swojej skrajnej formie odrzuca odczytywanie Biblii w kontekście ekologicznym jako owoc sekularyzmu i dzieło Szatana. ${ }^{14}$ Ten rodzaj lektury ma duży wpływ na chrześcijańskie przekonania i praktyki wśród fundamentalistów ewangelikalnych, którzy w efekcie odrzucają jakiekolwiek zainteresowania ekologiczne.

\section{Tekst, tlumaczenie i zagadnienia literackie}

Analizowane wersety stanowią część opowiadania o stworzeniu świata i człowieka (por. Rdz 1,1 - 2,1). Perykopa cieszy się dużym zainteresowaniem biblistów, którzy poświęcili jej ogromną liczbę opracowań. ${ }^{15}$ Badacze, próbując oddać jej literacką oryginalność, określają

rodzaju środowisk naturalnych i kulturowych, zob. np. F. C 1 i n g e r m a n, B. Tre a n o r, M. D r e n t h e n, D. U t s le r (red.), Interpreting Nature: The Emerging Field of Environmental Hermeneutics, New York 2014.

12 Por. D.G. H o r r e 11, Ecological criticism, w: P. G o o d e r (red.), Searching for Meaning: An Introduction to Interpreting the New Testament, London 2008, s. 192-198.

13 Por. E.M. C o n r a d i e, What on Earth is an Ecological Hermeneutics? Some Broad Parameters, w: D.G. H or re 11, C. H u n t, C. S o u th g a te, F. S t a v r a k o p o u lou (red.), Ecological Hermeneutics: Biblical, Historical and Theological Perspectives, London-New York 2010, s. 296-297.

14 Por. C. C u m b e y, The Hidden Dangers of the Rainbow: The New Age Movement and Our Coming Age of Barbarism, Lafayette 1983, s. 162-169.

15 Podstawową literaturę można znaleźć w: M. W o j c i e c h ow s k i, Pochodzenie świata, człowieka, zła, Częstochowa 2005; J. L e m a ń s k i, Księga Rodzaju, 
ją m.in. jako: opis stworzenia, historia, opowiadanie, a nawet hymn lub po prostu stworzenie świata. Jak pisze Janusz Lemański, fragment ten wydaje się zawieszony między poezją a opowiadaniem. ${ }^{16}$

Polecenie dane ludziom ma w tekście biblijnym dwie formy stanowiące klamrę obejmującą akt stworzenia człowieka na obraz Boży (por. Rdz 1,27). Najpierw wprowadza się je jako zamiar Boga (por. $\mathrm{Rdz} 1,26)$, następnie zaś ukazuje w formie imperatywu skierowanego wprost do ludzi (por. Rdz 1,27).

\section{$\operatorname{Rdz} 1,26$}

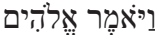

I powiedział Bóg:

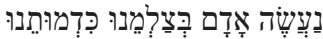

«Uczyńmy człowieka na Nasz obraz, podobnego Nam.

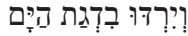

Niech panuje nad rybami morskimi,
$\operatorname{Rdz} 1,27$

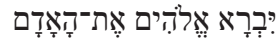

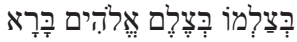

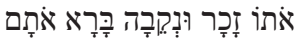
Stworzył więc Bóg człowieka na swój obraz, na obraz Boży stworzył go: mężczyzną i kobietą stworzył ich.

\section{Rdz 1,28}

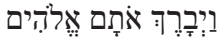
I błogosławił im Bóg,

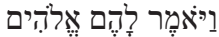
i powiedział im Bóg:

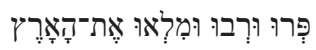

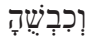
«Bądźcie płodni, i rozmnażajcie się, i napełniajcie ziemię, i ujarzmiajcie ją,

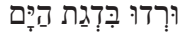
i panujcie nad rybami morza,

rozdziały 1-11. Wstęp - przekład z oryginału - komentarz, Nowy Komentarz Biblijny. Stary Testament I/1, Częstochowa 2013.

16 Por. tamie, s. 138. 


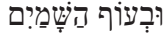

nad ptactwem

powietrznym,

וּבַבְּהָמָּה

nad bydłem,

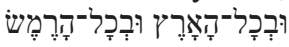

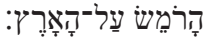

I nad całą ziemią, i nad

wszystkimi płazami

pełzającymi po ziemi!»

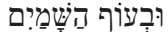

nad ptactwem niebios,

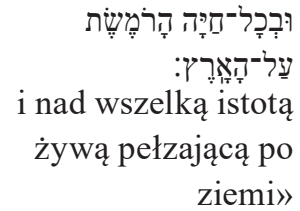

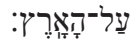

i nad wszelką istotą ziemi»

Z punktu widzenia ekologicznej hermeneutyki Biblii największe trudności w tym fragmencie sprawia rozumienie dwóch hebrajskich

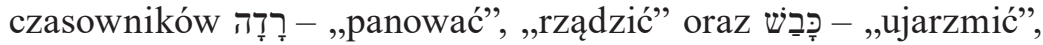
„zdeptać”, „zniewolić”, „upokarzać”. Problematyczne jest bowiem to, że pole semantyczne tych czasowników ma konotacje militarne. Dlatego też na początek przyjrzymy się słownikowemu znaczeniu tych rdzeni oraz ich użyciu w Piśmie Świętym.

Rdzeń רדה pojawia się zaledwie 27 razy w Biblii Hebrajskiej, z czego w Księdze Rodzaju tylko dwa razy, mianowicie w Rdz 1,26.28. Bardzo zróżnicowane tłumaczenia proponowane przez Septuagintę wskazują na trudności semantyczne związane z tym rdzeniem. ${ }^{17}$ Podmiot czasownika רְדָ ma zwykle formę osobową i dotyczy czynności wykonywanej przez ludzi - pojedynczo lub zbiorowo. Również dopełnieniem tego czasownika w przeważającej liczbie przypadków są jednostki lub grupy ludzkie. ${ }^{18}$ Odbiegają od tego jedynie dwa

17 Grupę czasowników greckich użytych do przetłumaczenia רְד tworzą:

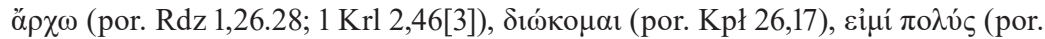

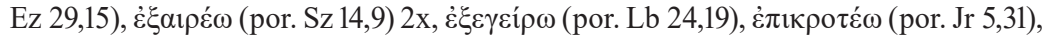

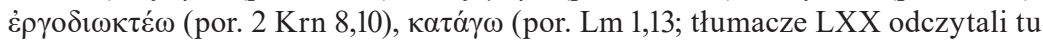

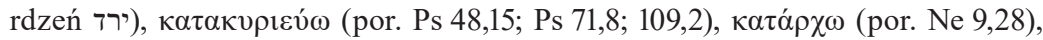

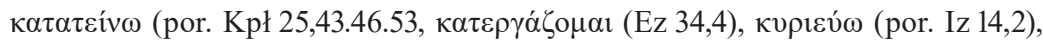
$\pi \alpha i \omega$ (por. Iz 14,6), $\pi \alpha \tau \varepsilon \dot{\omega} \omega$ (por. J1 4,13).

18 Por. H.J. Z o b e 1, רָדָ, w: G.J. B ot t e r w e c k, H. R i ng g r e n, H.J. F a b r y (red.), Theological Dictionary of the Old Testament, t. 13, Grand Rapids 2004, s. 331. 
teksty: J1 4,13, gdzie dopełnieniem jest tłocznia do wina, oraz właśnie $\operatorname{Rdz} 1,26.28$, gdzie chodzi o ziemię i całe królestwo zwierząt. Rdzeń ten funkcjonuje w Piśmie Świętym w świeckim kontekście, odnosząc się do władzy królewskiej, a dokładnie do sprawowania zwierzchnictwa nad obcymi lub wrogimi narodami (por. Ps 110,2; 72,$8 ;$ Lm 1,13). Pociąga to za sobą częste powiązanie tego rdzenia z aktami przemocy oraz motywem gniewu. Na tym tle wyróżnia się tekst dotyczący oceny postępowania pasterzy Izraela (Ez 34,4), z którego wynika, że sprawowanie władzy, panowanie nie musi automatycznie pociągać za sobą użycia siły.

Wydaje się, że odniesieniem dla zrozumienia idei panowania wprowadzonej przez czasownik רִ רָדה nie jest kontekst władzy królewskiej, ale specyficzne spojrzenie zawarte w kontekście narracyjnym $\operatorname{Rdz} 1,1$ - 2,3. Chodzi bowiem o współudział w boskim panowaniu nad Ziemią i zamieszkującymi ją stworzeniami. A to oznacza poszanowanie ich odrębności gatunkowej i ustanowionego przez Boga porządku stworzenia. Autor łączy tu sprawowanie panowania przez ludzi ze stworzeniem ich na obraz i podobieństwo Boga (por. $\mathrm{Rdz} 1,26)$, jednocześnie rozumiejąc je jako błogosławieństwo od Boga (por. Rdz 1,28).

Rdzeń כּכ כש występuje w Starym Testamencie zaledwie 14 razy, w większości w późnych tekstach. ${ }^{19}$ Septuaginta oddaje go różnymi terminami, których pole semantyczne odpowiada grupie kilku innych hebrajskich czasowników związanych z użyciem siły. ${ }^{20} \mathrm{~W}$ przypadku

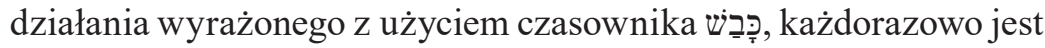
ono co najmniej dopuszczone przez Boga. Pojawia się w kilku kontekstach: działań wojennych, kiedy podbite zostaje całe terytorium wraz z ludnością (Lb 32,22-29; Joz 18,1; 1Krn 22,18), osobistym, gdy

\footnotetext{
19 Por. S. W a g n e r, כָכָ w: tamże, t. 7, Grand Rapids 1995, s. 53-54.

20 Grupę czasowników greckich użytych do przetlumaczenia כָָָּ tworzą:

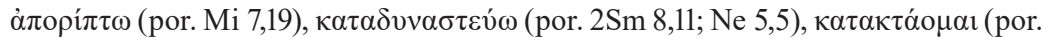

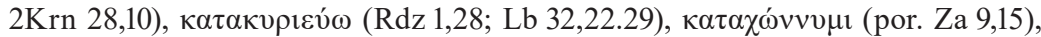

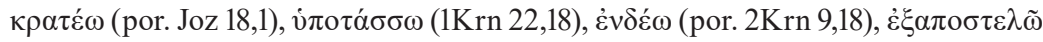
(por. Jr 34,16), غ̇ंı $\pi i ́ \pi \tau \omega$ (por. Est 7,8), $\omega \theta \varepsilon \dot{\varepsilon} \omega$ (por. Jr 34,11).
} 
ktoś dostaje się do niewoli (2Sm 8,11; Jr 34,11. 16; 2Krn 28,10) oraz w odniesieniu do przemocy na tle seksualnym (Est 7,8; Ne 5,5). W przypadku, gdy jego dopełnienie stanowi rzeczownik אֶ -,,ziemia”, כָָּ oznacza „zająć”, „wziąć w posiadanie” (por. Lb 32,22-29; Joz 18,1; 1Krn 22,18) i chodzi tu bardziej o wymiar terytorialny niż agrarny. Pole semantyczne tego czasownika obejmuje także podbicie i podporządkowanie ludności, jak również korzystanie z ekonomicznego i kulturowego potencjału związanego z ideą ziemi, która ma najszerszy zasięg semantyczny w Rdz 1,28, gdzie odnosi się do całego obszaru zdatnego do zamieszkania. Gdy natomiast dopełnieniem כָּבַש jest człowiek, przyjmuje znaczenie „ujarzmić”, „podbić” (por. 2Sm 8,11; Est 7,8; Jr 34,11).

W przypadku czasownika כָָּ większość kontekstów jego występowania implikuje zatem użycie jakiejś siły i zakłada obecność strony zarówno słabszej, jak i silniejszej. Nie musi, co prawda, pociągać za sobą stosowania przemocy implicite. Należy zauważyć, że w kontekście Rdz 1 wzięcie Ziemi w posiadanie nie oznacza wcale objęcia pustego terytorium - Ziemia jest już bowiem zamieszkana przez istoty inne niż człowiek, gdyż ten został stworzony jako ostatni. Tak więc owo „objęcie w posiadanie” może uwzględniać konieczność zdobywania Ziemi z towarzyszeniem mniejszego bądź większego wysiłku i użycia siły. W Rdz 1,28 czasownik ten stanowi ogniwo łączące temat płodności z pierwszej części wersetu z obecnym w drugiej części motywem dominacji. ${ }^{21}$ Objęcie ziemi w posiadanie jest więc połączone z jej zapełnianiem.

\section{Rdz 1,26-28 w ujęciu apologetycznego nurtu hermeneutyki ekologicznej}

W ocenie zwolenników nurtu apologetycznego, zwanego też hermeneutyką apologetyczną (apologetic hermeneutic) lub hermeneutyką odzysku (hermeneutic of recovery), z ekologicznego punktu

21 Por. Z. P aw ło w s k i, Opowiadanie Bóg i początek. Teologia narracyjna $R d z$ 1-3, Rozprawy i Studia Biblijne 13, Warszawa 2003, s. 340. 
widzenia tekst biblijny Rdz 1,26-28 sam w sobie jest przyjazny środowisku naturalnemu. Zdaniem Richarda Bauckhama, pozytywna wizja człowieka jako odpowiedzialnego gospodarza jest nierozerwalnie związana z tekstem biblijnym, którego interpretacja uległa wypaczeniu dopiero $\mathrm{w}$ epoce renesansu - na fali fascynacji humanistów grecką myślą filozoficzną - a jeszcze bardziej w dobie oświecenia. ${ }^{22}$ W dyskusji ekologicznej należałoby więc dążyć do ukazania wartości tekstu natchnionego i odzyskania (recovery) jego pierwotnego sensu, który został wypaczony w tradycji interpretacji.

Podobne wnioski wyprowadził Norbert Lohfink, który sprzeciwiał się oddzielaniu Rdz 1,28 od kontekstu całego opowiadania o stworzeniu i pomijaniu jego kontekstu historyczno-kulturowego. ${ }^{23}$ Należy mieć wzgląd na fakt, że niczym refren przewija się w całym opowiadaniu, na długo przed stworzeniem człowieka, pozytywna ocena stworzenia w oczach Boga jako טוֹ - ,dobre” (por. Rdz 1,4.10.12.18.21.25), a na koniec jako מְאד טוֹב -, ,bardzo dobre” (por. Rdz 1,31). Wszystko więc, co Bóg stworzył, stanowiło wartość samą w sobie, nie zaś w służbie człowiekowi. Zgodnie z Rdz 1, Bóg ocenił je tak, zanim człowiek został stworzony. Według autora natchnionego, kompletne dzieło stworzenia oglądane jako harmonijna całość zostało dookreślone przysłówkiem „bardzo”. Ma to tym większą wagę, że w kosmogoniach ościennych znanych Izraelitom materia stworzenia świata i człowieka jest zła, demoniczna i w sumie przejmuje grozą, wymaga też jakiejś siły, która trzymałaby ją w ryzach ${ }^{24}$. Z drugiej jednak strony należy również pamiętać, że obraz Rdz 2, prezentujący odmienną kolejność stwarzania, uzasadnia istnienie istot żywych ich zdatnością do pomocy człowiekowi (por. Rdz 2,18). Księga Rodzaju wnosi więc przede wszystkim w swoim kontekście kulturowym nowe

22 Por. R. B a u ck ha m, God and the Crisis of Freedom: Biblical and Contemporary Perspectives, Louisville 2002, s. 141.

23 Por. N. L o h f i n k, Unsere großen Wörter. Das Alte Testament zu Themen dieser Jahre, Freiburg 1977, s. 156-171.

24 Por. P. D e Plu n ket t, Ekologia-stereotypy i rzeczywistość, s. 25-27. 
spojrzenie na naturę świata i człowieka, który, pochodząc od dobrego Boga, sam jest dobry, uporządkowany oraz piękny.

Zdaniem Gabriela Witaszka, „ekologiczne zadanie Księgi Rodzaju" 25 mają w tej koncepcji wyrażać hebrajskie czasowniki opisujące w Rdz 1-2 relację człowieka do stworzenia: רָדָ - ,panować” (por. Rdz 1,26.28) i שָָּ - ,zająć”, ,wziąć w posiadanie” (por.

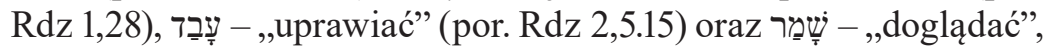
"strzec” (por. Rdz 2,15). Proponowane rozumienie czasownika רָדָר skupia się w tej interpretacji wokół odpowiedzialnego gospodarowania bez przemocy. Takie rozumienie tego rdzenia występuje np. w Ez 34,4, gdzie prorok przedstawia władców Izraela jako pasterzy pełnych przemocy i okrucieństwa zamiast troski i współczucia. ${ }^{26}$ Zdaniem Norberta Lohfinka, tłumaczenie czasownika רִ jako „towarzyszyć”, „paść”, „przewodzić” i „rozkazywać” odpowiada starożytnej myśli łączącej w sobie ideę władcy i pasterza. ${ }^{27}$ Gabriel Witaszek stwierdza: ,...nie oznacza to przecież niszczenia, lecz zachowanie, strzeżenie i korzystanie nie tyle według potrzeb, ile zgodnie z naturą i siłami istot stworzonych". ${ }^{28}$ Panowanie nad innymi istotami jest tu specyficznie rozumiane jako prawo do oswajania zwierzą ${ }^{29}$ oraz wykorzystywania ich do pracy. ${ }^{30} \mathrm{Na}$ przeszkodzie tej tezie nie stanęła nawet świadomość braku w katalogu Bożego polecenia dotyczącego trzody i bydła. Pełni pozytywnego obrazu człowieka dopełnia odwołanie się do idei pasterza opiekującego się

25 Por. G. W it a s z e k, Kościół wobec ekologii, Zeszyty Naukowe KUL 36(1993) nr 141-144, s. 46.

26 Por. R. B a u c k h a m, Bible and Ecology. Rediscovering the Community of Creation, London 2010, s. 18.

27 Por. N. L o h f i n k, Unsere großen Wörter, s. 166.

28 G. W it a s z e k, Kościół wobec ekologii, s. 44-45.

29 Por. A.J. N a j d a, Początki ekologii w Biblii, Studia Ecologiae et Bioethicae 2/2004, s. 146-148.

30 Tamże, s. 145; J. S u c hy, Czyńcie sobie ziemię poddana, panujcie nad zwierzętami, Zeszyty Naukowe KUL 36(1993) nr 141-144, s. 14. 
stadem. ${ }^{31}$ Wyższość człowieka nad pozostałymi stworzeniami objawia podobieństwo do Boga. Miałaby to więc być władza empatyczna i troskliwa, nie zaś dominująca i eksploatująca. Skutkiem wypaczenia tego pierwotnego, wartościowego przesłania była interpretacja antropocentryczna, usprawiedliwiająca egoistyczne wykorzystanie przyrody przez człowieka do własnych celów.

Uzasadnienie panowania nad stworzeniem stanowią wersety poprzedzające polecenie dane człowiekowi. Na szczególne zaangażowanie Boga wskazuje przytoczenie w mowie niezależnej Jego

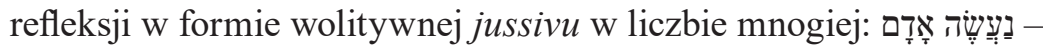
„uczyńmy człowieka” (por. Rdz 1,26). Wyjątkową rolę człowieka w Jego stwórczym planie podkreśla dalszy komentarz narratora obraz i podobieństwo Boże (por. Rdz 1,27) dają człowiekowi szczególną pozycję wśród stworzeń. Nie pozostaje on jednak oddzielony od świata, ${ }^{32}$ lecz zamieszkuje go i troszczy się o niego jako o swoje środowisko życiowe.

Istotną rolę w tej argumentacji odgrywa odwoływanie się do autorytetu starszeństwa tzw. jahwistycznego opowiadania w Rdz 2, w którym to Bóg nakazuje człowiekowi עָברב - ,uprawiać” ogród Eden oraz שֵַָׁר - ,strzec” go (por. Rdz 2,15), co niewątpliwie ma wydźwięk pozytywny. Adam, ulepiony tak jak inne stworzenia z prochu ziemi, otrzymuje szczególną godność nadawania zwierzętom imion, oznaczającą przejęcie nad nimi władzy (por. Rdz 2,7.19-20). Bóg uczynił człowieka kustoszem stworzenia, dlatego jego zadaniem jest troska i odpowiedzialność za Ziemię, pozostawanie z nią w bliskiej relacji, uprawianie jej i żywienie się jej owocami. ${ }^{33}$ Człowiek otrzymał błogosławieństwo bycia płodnym i napełnienia Ziemi, tak samo jak stworzenia morskie i ptaki odpowiednio do swojej przestrzeni życiowej. Polecenie panowania nad stworzeniem postrzegać

31 Por. te n ż e, Ekologiczne przesłanie Biblii, w: G. W i t a s z e k, (red.), Życie społeczne w Biblii, Lublin 1997, s. 178-179.

32 Por. G. W it a s z e k, Kościół wobec ekologii, s. 44; J. S u c h y, Ekologiczne przesłanie Biblii, s. 176.

33 Por. R. B a u c k h a m, Bible and Ecology, s. 22. 
należy przez pryzmat roślinożerności pierwszych ludzi i nie łączyć go z zabijaniem czy mięsożernością. ${ }^{34} \mathrm{~W}$ efekcie tej niezwykłej relacji między człowiekiem a resztą stworzenia konsekwencje grzechu pierwszych ludzi dotkną także Ziemię (por. Rdz 3,17-19) i dopiero z czasem zwierzęta zaczną lękać się ludzi, którzy zaczną zabijać je na pokarm (por. Rdz 9,2-3).

\section{Rdz 1,26-28 w ujęciu radykalnego nurtu hermeneutyki ekologicznej}

Zdaniem zwolenników nurtu radykalnego (radical hermeneutic), odwołujących się do hermeneutyki podejrzeń i oporu (hermeneutic of suspicion and resistance), problem leży w samych tekstach biblijnych, które są skrzywione antropocentrycznie, a przez to nie uwzględniają perspektywy całego ekosystemu, którego równoprawnymi członkami są byty niebędące ludźmi. ${ }^{35}$

Podejrzenie (suspicion) dotyczące antropocentrycznej orientacji opowiadania o stworzeniu znajduje, ich zdaniem, swe potwierdzenie w tekście biblijnym. Widać to w momencie, gdy zostaje zachwiany rytm opisu stworzenia świata (początkowo to Ziemia jest partnerką Boga w stwarzaniu, a wszystkie stworzenia są sobie równe) i uwaga skupia się na ukazaniu uprzywilejowanej pozycji ludzi w relacji z Bogiem (jako jedyni zostali stworzeni na obraz i podobieństwo Boże oraz otrzymali mandat do panowania nad całym stworzeniem). Narracja uzasadniająca szczególny status człowieka i dająca teologiczne podstawy jego panowania nad naturą wprowadza przepaść między nim a resztą świata stworzonego, która ujawnia się w wyzysku i niesprawiedliwości względem Ziemi ze strony rodzaju

34 Por. J. S u c hy, Ekologiczne przestanie Biblii, s. 179.

35 Por. N.C. H a b e 1, Introducing The Earth Bible Commentary Series, w: te nże, The Birth the Curse and the Greening of Earth. An Ecological Reading of Genesis 1-11, Earth Bible Commentary 1, Sheffield 2011, s. 8; t e n ż e, Introducing The Earth Bible Commentary Series, w: t e n ż e, Finding Wisdom in Nature. An Eco-Wisdom Reading of the Book of Job, Earth Bible Commentary 4, Sheffield 2014, s. 4. 
ludzkiego. ${ }^{36}$ Analizowany fragment może zostać ukazany w nowym świetle dzięki identyfikacji (identification) czytelnika z bytami niebędącymi ludźmi, które jako postaci zostały w tekście przemilczane. Dopełnienie zabiegu identyfikacji stanowi przywrócenie (retrieval) w narracji głosu całej społeczności Ziemi.

Reprezentanci tego nurtu podkreślają, że uważna analiza opowiadania o stworzeniu w Rdz 1 dowodzi, że Ziemia odgrywa w nim istotną rolę. Jako postać zostaje wprowadzona już w Rdz 1,1-2, gdzie oczekuje w pierwotnych wodach na swoje narodziny - geofanię ${ }^{37}$ w trzecim dniu stwarzania. Od tego momentu staje się podmiotem działania i partnerką Boga w dziele stworzenia. Nie można więc lekceważyć jej roli jako matki wydającej na świat wszystko, co istnieje. Tym bardziej niezrozumiałe staje się stłumienie jej pozytywnego obrazu w Rdz 1,25-28. Jako remedium na taki stan rzeczy jest postulowana dekonstrukcja tekstu, który nie deprecjonuje i nie marginalizuje roli przyrody, oraz idąca w ślad za nią rekonstrukcja, mająca na celu kreatywne opracowanie nowych wersji tekstów, które uwzględnią perspektywę całej społeczności Ziemi, zgodnie z założeniami przyjętymi w ramach The Earth Bible Project - międzynarodowej i międzywyznaniowej grupy naukowców pod przewodnictwem Normana C. Habla. Polegają one po pierwsze, na podejrzeniu (suspicion) w odniesieniu do antropocentryzmu danego tekstu, po drugie na identyfikacji (identification) z Ziemią i bytami nie będącymi ludźmi, na końcu zaś na przywróceniu (retrieval) tekstowi perspektywy lub głosu Ziemi. Taką rekonstrukcję tekstu Biblii zaproponował np. Norman C. Habel. ${ }^{38}$

36 Por. te $\mathrm{n} \dot{\mathrm{z}} \mathrm{e}$, The Birth, the Curse and the Greening of Earth, s. 37-38.

37 Por. t e n ż e, Geophany: The Earth Story in Genesis One, w: N.C. H a b e 1, S. W u r s t (red.), The Earth Story in Genesis, Earth Bible 2, Sheffield 2000, s. 34-48.

38 N.C. H a b e 1, wyniki swoich poszukiwań zaprezentował w referacie: „Playing God or Playing Earth?" An Ecological Reading of Genesis 1.26-28, wygłoszonym 20 XI 2005 r. podczas 2005 SBL Annual Meeting w Filadelfii (Sesja S20-113); tekst został opublikowany w: F. G a i s e r, M. Th r o n t ve it (red.), „And God Saw That It Was Good". Essays on Creation and God in Honor of Terence E. Fretheim, Word and World Supplement Series 5, Saint Paul 2006, s. 33-41. Trzy lata później 
Dla stworzeń szczególnie brzemienne są konsekwencje udzielonego ludziom błogosławieństwa. Z mandatu Bożego mają oni כָּבָָּ „ujarzmiać”, „deptać” oraz רִדָ - „rządzić”. Te same czasowniki, które dla nurtu apologetycznego decydowały o ekologicznym zadaniu wypływającym z tej perykopy, według zwolenników radykalnej formy hermeneutyki ekologicznej są punktem zapalnym dyskusji i problemem, którego nie można przemilczeć. Ich zdaniem, nie sposób bowiem ignorować agresywnego i negatywnego wydźwięku tych czasowników. ${ }^{39} \mathrm{Nie}$ został on zlekceważony przez antropocentrycznie zorientowanych redaktorów Księgi Rodzaju. Celem narracji było bowiem ukazanie wyjątkowej relacji człowieka z Bogiem i wynikającej z niej szczególnej pozycji ludzi względem stworzeń oraz potwierdzenie, że od początku świata wpisane zostały w nią przemoc i wyzysk.

\section{Rdz 1,26-28 w ujęciu neoortodoksyjnego nurtu hermeneutyki ekologicznej}

Reprezentanci nurtu neoortodoksyjnego doceniają starania zwolenników nurtu dekonstrukcyjnego i rekonstrukcyjnego dotyczące oczyszczania przesłania Biblii. Z drugiej jednak strony negatywnie oceniają zawłaszczanie przez nich tekstów biblijnych i dewaluowanie wielowiekowej tradycji judeochrześcijańskiej, która jest zbyt bogata, by można postrzegać ją wyłącznie w jasnych lub ciemnych barwach. Ostrzegają przy tym przed traktowaniem opowiadania o stworzeniu jako wiernego opisu wydarzeń. ${ }^{40} \mathrm{~W}$ zamian proponują podejście rewizjonistyczne (revisionist hermeneutic), polegające na rewizji

przedstawił bardziej rozbudowaną wersję tej rekonstrukcji; zob. N.C. H a b e 1, The Birth, the Curse and the Greening of Earth, s. 44-45.

39 Por. t e n ż e, „Playing God or Playing Earth?”, s. 39; J. L e m a ń s k i, Księga Rodzaju, rozdziaty 1-11, s. 172.

40 Por. J.W. R og e r s o n, The Creation Stories: Their Ecological Potential and Problems, w: D.G. Hor re 11, C. Hu n t, C. S o u th g a t e, F. S t a v r a k op oulou (red.), Ecological Hermeneutics: Biblical, Historical and Theological Perspectives, s. 27. 
i odczytaniu w sposób ekologicznie krytyczny, zarówno samych perykop, jak i odnoszących się do nich tradycji interpretacyjnych.

Rewizjoniści zwracają uwagę na konieczność interpretacji fragmentu Rdz 1,26-28 w odniesieniu nie tylko do całej perykopy Rdz 1,1 2,3, lecz także do jej miejsca w strukturze narracyjnej sekcji Rdz 1-9. Zanim zaistniał człowiek, nastąpiło bowiem stworzenie warunków, umożliwiających jego bytowanie. Nie należy jednak ograniczać ich roli do stanowienia środowiska życiowego człowieka, który jest komplementarnie związany z całym stwórczym dziełem Boga. W tym procesie aktywnie uczestniczy Ziemia, która status podmiotu zyskuje już w Rdz 1,11. W pierwszych pięciu dniach stwarzania Ziemia występuje w narracji jako postać ${ }^{41}$ aktywnie uczestnicząca w procesie stwarzania, którego poszczególne akty inicjuje, a następnie aprobuje

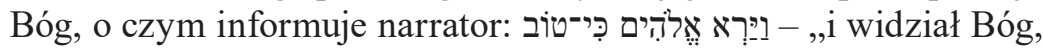
że było dobre" (por. Rdz 1,4.10.12.18.21.25). ${ }^{42}$ Celem nadrzędnym całego stworzenia jest oddawanie czci Bogu, co wyraża ustanowienie szabatu w dniu siódmym (por. Rdz 2,2-3).

W kolejnych wersetach (por. Rdz 1,29-30) wyznaczona zostaje nieprzekraczalna granica warunkująca harmonię bytów stworzonych. Istoty żywe - zarówno człowiek, jak i zwierzęta - mają być roślinożerni. Podkreślenie tego aspektu wyraźnie osłabia aspekt agresji, drapieżności i mięsożerności, suponowany w czasownikach רדזה oraz כבש wskazujących na dominację człowieka nad przyrodą.

Panowanie nad przyrodą z mandatu Bożego ma swoje granice, o czym autorzy natchnieni będą wielokrotnie przypominać na kartach Pisma Świętego, doprecyzowując intuicje zawarte w Rdz 1,1 - 2,3. Człowiek nie został bowiem ustanowiony panem całego stworzenia, ale raczej jego zarządcą, którego obowiązkiem jest respektować prawa dane przez Stwórcę. Zauważali to też komentatorzy średniowieczni, którzy odczytywali to opowiadanie jako zachętę do tworzenia równowagi i harmonii istot stworzonych. Nadmierną eksploatację

41 Por. Z. P a w ło w s k i, Opowiadanie Bóg i początek, s. 314.

42 Por. W.P. B row n, Structure, Role, and Ideology in the Hebrew and Greek Texts of Genesis 1:1 - 2:3, Atlanta 1993, s. 95-100. 
przyrody, występującą wbrew pierwotnemu porządkowi, rozumiano jako skutek nieuporządkowania, spowodowanego grzechem człowie$\mathrm{ka}^{43}$ To grzech spowodował stopniową degenerację rodzaju ludzkiego, a wraz z nią upadek całego stworzenia. Ukazują to kolejne rozdziały Księgi Rodzaju, kulminacja zaś następuje w sekcji Rdz 6-9 opowiadającej o Noem i potopie. Nieprzyjaźń między światem ludzi a światem zwierząt i zabijanie ich na pokarm pojawia się dopiero po potopie (por. Rdz 9,1-7), gdzie Bóg ponawiając swoje błogosławieństwo dla ludzi, daje jednocześnie synom Noego przyzwolenie na spożywanie zwierząt. W koncentrycznej strukturze narracji Rdz 1-9 $9^{44}$ został podkreślony rozdźwięk między Bożym planem a jego wypełnieniem, a właściwie niewypełnieniem przez człowieka. Potop jest odwróceniem procesu stwarzania, a jednocześnie początkiem nowego porządku. W tym kontekście jawi się jako sąd Boga nad stworzeniem, a siły natury, zwłaszcza zaś woda pochodząca z nieba, stają się wykonawcami Bożego wyroku. ${ }^{45}$ Zakres potopu jest ograniczony do świata fauny na Ziemi. Kataklizmem nie zostaje dotknięte ani morze i jego mieszkańcy, ani Ziemia, która zachowuje płodność i natychmiast po ustaniu potopu rodzi roślinność (por. Rdz 8,11), nie zostaje też zachwiany porządek w niebie. Niezachwiany pozostaje również czas i pory roku. Bóg angażuje się w ocalenie sprawiedliwych i reprezentantów wszystkich gatunków, kierując akcją ratunkową i osobiście zamykając drzwi arki (por. Rdz 7, 16).

Ocaleni wnoszą ze sobą do odnowionego świata skażenie grzechem. Jest to zatem świat kompromisu, w którym Bóg zostawia miejsce nie tylko dla ludzkiej wolności, jak dotychczas, ale też dla ludzkiej słabości. Bóg w kolejnym błogosławieństwie rozszerza władzę człowieka (por. Rdz 9,1-3). Odtąd inne stworzenia odczuwają przed nim lęk i zostają przeznaczone dla niego na pokarm, wciąż

43 Por. G. O v it t, The Restoration of Perfection: Labor and Technology in Medieval Culture, London 1987, s. 70-85.

44 Por. J. L e m a ń s k i, Księga Rodzaju, rozdziały 1-11, s. 28-31.

45 Obraz niszczycielskiej siły wody jest w Biblii obecny w wielu miejscach, np. Ps 93,1-2; 18,16; 65,5-8; 60,1; 89,9; Iz 24,18; Dn 9,26. 
jednak utrzymana zostaje nieprzekraczalna granica, wyrażona zakazem spożywania krwi (por. Rdz 9,4). Po ponowieniu mandatu panowania nad stworzeniem (por. Rdz 9,7) Bóg zawiera przymierze nie tylko z Noem i jego rodziną, ale z całym stworzeniem (por. Rdz 9, 9-10).

Zwolennicy nurtu neoortodoksyjnego twierdzą, że fragment Rdz 1,26-28 odczytany w kontekście Rdz 1-9 nie motywuje, ani tym bardziej nie zezwala na nadmierne czy dowolne eksploatowanie świata przez ludzi, lecz stanowi krytykę zachowania człowieka wobec stworzenia i zła, które leży u jego podstawy. W ich ocenie polecenie Boga z Rdz 1,26-28, aby człowiek panował nad stworzeniem, ma charakter prorocki i jawi się jako ideał, do którego realizacji należy dążyć. ${ }^{46}$ Stanowi zaproszenie do stworzenia wspólnoty zdolnej do życia w świecie zgodnym z Bożym zamiarem.

Nie bez znaczenia jest tu odniesienie do całości kanonu biblijnego, gdyż motyw troski człowieka o stworzenie jest podejmowany także przez innych autorów natchnionych Starego Testamentu (np. Pwt 5,12-16; Prz 12,10; Oz 2,20). W Nowym Testamencie walor ten zostaje podkreślony jeszcze wyraźniej. Szczególną rolę odegrało tu posłannictwo Jezusa. Praktyka składania ofiar ze zwierząt została trwale i skutecznie zastąpiona jedyną ofiarą złożoną przez Chrystusa na krzyżu (por. Hbr 10,1-18). Jest to klucz do urzeczywistniania świata zgodnego z Bożymi zamiarami nie tylko w wymiarze eschatologicznym, lecz także już tu, na ziemi. W ocenie rewizjonistów dopiero taka interpretacja oddaje intencje redaktorów tekstu natchnionego, który nie stanowi wywodu naukowego, lecz mit, rozumiany jako opowiadanie o pochodzeniu otaczającego świata, którego harmonia została zaburzona przez nieposłuszeństwo pierwszych rodziców, a reperkusje tego występku są boleśnie odczuwalne aż do naszych czasów, nie tylko przez ludzi. ${ }^{47}$

46 Por. J.W. R o ge r s o n, The Creation Stories, s. 26.

47 Por. tamże, s. 27; por. J. L e m a ń s k i, Księga Rodzaju, rozdziały 1-11, s. 137;

Z. P a wło w s k i, Narracja i egzystencja. Genesis whermeneutyce opowieści, Toruń 2013, s. 99. 


$$
* * *
$$

Współczesny kryzys ekologiczny jest fenomenem złożonym i wielowątkowym. Należy sobie uświadomić, że „ekologia fizyczna pozostaje w ścisłym związku z ekologią ludzką"48 i nie da się ich rozpatrywać osobno, gdyż niezaprzeczalnie i nieustannie człowiek i środowisko oddziałują na siebie. W biblijnym opowiadaniu o stworzeniu wyraźnie zostało podkreślone, że Ziemia została stworzona przed człowiekiem, a Bóg przekazał mu ją jako dar, wyznaczając jednocześnie granice jego władzy. Co więcej, Ziemia, stanowiąca pewną organiczną całość, ma własną genealogię $(\operatorname{Rdz} 2,4) .{ }^{49}$ Faktem jest, że tekst biblijny nie ma charakteru biocentrycznego, jak życzyliby sobie zwolennicy radykalnej formy hermeneutyki ekologicznej. Warto jednak w tym miejscu zauważyć, że wbrew ich przekonaniu nie ma on jednak także charakteru wyłącznie antropocentrycznego, lecz charakter teocentryczny. Człowiek nie jest celem sam w sobie. Tradycja judeochrześcijańska łączy bowiem akt stworzenia z Bożym planem miłości, w którym w istnienie każdej istoty wpisana jest niezbywalna wewnętrzna wartość bycia dziełem Boga. W ujęciu hermeneutyki ekologicznej (niezależnie od jej nurtu) wyjątkowy status człowieka nie uprawnia go zatem do dowolnej czy nadmiernej eksploatacji środowiska naturalnego, lecz nakłada na niego obowiązek patrzenia na to dzieło z uwzględnieniem perspektywy Boga i uznania, że inne stworzenia są dla Niego wartościowe same w sobie oraz że on sam, człowiek, jest również stworzeniem. Istnienie świata nie jest dziełem przypadku lub też ubocznym skutkiem innych działań podejmowanych przez bóstwa, jak sugerowały to mitologie ludów ościennych ${ }^{50}$ w czasie powstawania tekstu Biblii, lecz wynika z wolnej decyzji

\footnotetext{
48 P. D e Plunkett, Ekologia-stereotypy i rzeczywistość, s. 161.

49 J. L e m án s k i, Genealogie Rdz 1-11, Collectanea Theologica 83(2013)4, s. $12-14$.

50 Por. te n ż e, Księga Rodzaju, rozdziaty 1-11, s. 122-131.
} 
Boga. Wszystkie stworzenia - jako Jego dzieła - odzwierciedlają W sobie promień Bożej mądrości i dobroci. ${ }^{51}$

Przytoczone stanowiska jasno wykazują, że odczytanie polecenia z Rdz 1,26-28, by człowiek panował nad Ziemią, w kluczu hermeneutycznym uwzględniającym okoliczności powstania oraz specyfikę tekstu biblijnego, nie oznacza usprawiedliwienia dla degradacji środowiska naturalnego ani też rezygnacji z użytkowania bogactw natury. Podnoszona współcześnie ze szczególnym nasileniem teza, że wszystko, co technicznie możliwe, jest dobre i powinno być dozwolone, mija się z prawdą. Konieczna jest bowiem także zgodność podejmowanych przez człowieka działań z normami etycznymi mającymi wzgląd na Boże prawo. Także wbrew wcześniejszym twierdzeniom wiemy już dziś, że zasoby naturalne nie są niewyczerpane, technologia zaś nie zastąpi obecnej na Ziemi bioróżnorodności i złóż surowców.

Panowanie nad siłami natury w harmonii z całą wspólnotą Ziemi jest nie tylko możliwe, ale wręcz konieczne. W tym celu należy wykorzystywać odnawialne źródła energii, którymi są m.in. promienie słoneczne, wiatr, opady deszczu, płynąca woda czy geotermia. Metody te są znane ludzkości od wieków, mogą przecież być wciąż udoskonalane, a nawet zmieniane zgodnie z obecnym stanem wiedzy. Celem jest bowiem takie użytkowanie różnorodności biologicznej, które nie powoduje znacznych szkód dla środowiska, bez którego człowiek nie jest w stanie przeżyć. Jednakże przezwyciężanie rozwijanego w ekonomii mitu nieskończonego postępu i konsumpcjonizmu ${ }^{52} \mathrm{wy}-$ maga chrześcijańskiego zaangażowania i troski o zachowanie Bożego dzieła i niewykorzystywanie go ponad to, co konieczne do istnienia. Kluczową rolę odgrywa tu ćwiczenie się w cnocie umiarkowania i nieuleganie sztucznie kreowanym potrzebom ciągłej konsumpcji.

Tomasz TWARDZIŁOWSKI

51 Por. Katechizm Kościoła Katolickiego, nr 339.

52 Por P. D e Plunkett, Ekologia-stereotypy i rzeczywistość, s. 145-146. 
Słowa kluczowe: ekologia, ekologiczna hermeneutyka Biblii, Rdz 1,26-28

Keywords: Ecology, Ecological hermeneutics of the Bible, Gen 1:26-28

\section{The Command to Rule over Creation (cf. Gen 1:26-28) in the Ecological Hermeneutics of the Bible}

\section{Summary}

The divine command given to a man (cf. Gen 1:26-28) has been a matter of concern in biblical scholarship for centuries. In the last decades, theologians and biblical scholars have tried to re-read this passage in view of the environmental crisis. This paper starts with an overview of the development of a new proposal - the ecological hermeneutics of the Bible. Particular paragraphs present results of the application of various ecological hermeneutical forms to the passage Gen 1:26-28: apologetic, radical and revisionist (neo-orthodox). The apologetic form perceives the text of the Bible as a friendly one to the environment and develops the idea of responsible human stewardship. It emphasizes the role of man as a custodian of creation. The radical form, by contrast, perceives the same texts as infected anthropocentrically. The order of command over creation introduces enmity between man and nature that is disclosed through exploitation and injustice towards the earth from the part of humankind. Therefore, it proposes a reconstruction of the text retrieving the voice of the earth. Representatives of a revisionist form claim instead that the passage Gen 1:26-28 re-read in the context of Gen 1-9 does not allow people to exploit the natural environment and it criticizes peoples' behavior towards creation. The analysis shows that reading the divine command of human dominion in Gen 1:26-28 in a hermeneutical light considering the circumstances and specificity of the biblical text means neither the justification of the degradation of the natural environment, nor the refraining from gaining benefits from its natural resources. 